\title{
Does curcumin protect against hazards of aspartame intake on the cerebellar cortex of male adult albino rats? Histological and immunohistochemical study
} Original Article

Ibrahim Hassan Ibrahim

Department of Anatomy and Embryology, Faculty of Medicine, Zagazig University, Sharkia, Egypt

\begin{abstract}
Background: Aspartame is an artificial sweetener and unfortunately its intake might cause a dangerous effect on the cerebellar cortex. Curcumin has a neuroprotective role in many diseases.

Objective: The study aimed to assess the possible ameliorating role of curcumin against the structural changes of cerebellar cortex that had been associated with aspartame administration in adult wistar rats.

Materials and Methods: 48 male adult wistar rats were divided equally into 4 groups. Group I or control, group II or curcumin group each rat received curcumin $100 \mathrm{mg} / \mathrm{kg} /$ day, group III, each rat received aspartame $250 \mathrm{mg} / \mathrm{kg} / \mathrm{day}$ and in group IV, each rat received curcumin and aspartame as group II and group III concomitantly. The doses were given orally once daily for 8 weeks. By the end of the experiment, all animals were sacrificed, specimens of cerebellum were processed and stained with hematoxylin and eosin, Glial Fibrillary Acidic Protein (GFAP) and caspase-3 for histological and immunohistochemical studies. Morphometric and statistical studies were performed.

Results: Cerebellar cortex of aspartametreated group showed features of neurodegeneration of purkinje cells with areas of neuropil loss in the molecular and granular layers. Also, area percentage of GFAP immunoexpression was increased. The number of purkinje cells that showed positive immunoreaction of caspase 3 was also increased. On concomitant administration of curcuminwith aspartame, the structural changes of cerebellar cortex were decreased.

Conclusion: Curcumin intake partially protects the cerebellar cortex from hazards of aspartame intake,so supplementation of curcuminin diet is recommended with regular intake of aspartame.
\end{abstract}

Key Words: Curcumin, aspartame, cerebellar cortex, adult rats.

Revised: 03 December 2019, Accepted: 31 December 2019

Corresponding Author: Ibrahim Hassan Ibrahim, Department of Anatomy and Embryology, Faculty of Medicine, Zagazig University, Sharkia, Egypt, Tel.: +201006501801, E-mail: ebrahimelazony5555@yahoo.com

ISSN:2536-9172, December 2019, Vol. 3, No. 2

\section{INTRODUCTION}

Aspartame is considered as one of the artificial sweeteners that is used to reduce the caloric intake in healthy persons ${ }^{[1]}$. It is used in many food products as breakfast cereals, soft drinks, chewable gums and vitamin supplements ${ }^{[2,3]}$. Aspartame is formed of 3 components that are phenylalanine, aspartic acid and methano ${ }^{[4]}$. Many reports suggested that there were behavioral changes, headache and neurological reactions with chronic consumption of aspartame ${ }^{[5]}$ that was concerned with toxicity of central nervous system ${ }^{[6]}$. Also, Okasha ${ }^{[6]}$ revealed that chronic consumption of aspartame resulted in structural changes on the sciatic nerve in albino rats. Otherwise, some studies stated that aspartame consumption is safe and there was no association between cancer of any organ and consumption of aspartame ${ }^{[7]}$. Curcumin is a yellow component and natural pigment in the turmeric. It is present in rhizome of the curcuma longa plant and has anti-inflammatory activity in animal models, human and cell culture ${ }^{[8]}$. Curcumin activates cytoprotectiveenzymes as GST (glutathione-Stransferase) and protects against hemin - induced neuronal toxicity. Also, curcumin has antioxidant activity as it scavenges reactive oxygen species (ROS $)^{[8]}$. This work aimed to study the possible protective role of curcumin against the changes of cerebellar cortex that had been associated with aspartame administration in adult wistar rats.

\section{MATERIALS AND METHODS}

\subsection{Animals:}

A total of forty-eight adult male wistar rats (average weight, 180-200 gm.) were obtained from the animal house unit, faculty of medicine, Zagazig University and were used in this study. The rats were housed in suitable cages under a normal daily 12 hours light/dark cycle and in a temperature controlled room, fresh water and standard food were available. For acclimatization, all rats were housed one week before the beginning of the experiment. 
This experimental study was approved in agreement with Institutional Animal Care and Use Committee, Zagazig University ( ZU-IACUC/3/F/20 /2019)

\subsection{Chemicals and solutions :}

Aspartame tablets were purchased from Al-Amerya pharm. Ind., Egypt and each tablet contains $20 \mathrm{mg}$ aspartame that was crushed and dissolved in distilled water.

Curcumin in the form of powder (Sigma - Aldrich company, St Louis, Missouri, USA ) dissolved in corn oil.

\subsection{Experimental design :}

The rats were divided into four equal groups, each group including 12 rats.

-Group (I) or control group in which, the rats were subdivided equally into 2 subgroups, subgroup I (A) as a negative control, in which each rat received $1 \mathrm{ml}$ distilled water and subgroup I(B) in which each rat received $1 \mathrm{ml}$ corn oil .

-Group (II) or curcumin group, in which each rat received curcumin dissolved in corn oil $(100 \mathrm{mg} / \mathrm{kg} / \text { day })^{[9,10]}$.

-Group (III) or aspartame group in which each rat was given aspartame dissolved in distilled water $(250 \mathrm{mg} / \mathrm{kg} /$ day $)$ and this dose was adjusted to correspond the acceptable intake of aspartame per day in human as determined by world health organization (40-50 $\mathrm{mg} / \mathrm{kg} /$ day), then this dose was increased up to 5 times as the rats metabolize aspartame faster than human $^{[6]}$.

-Group (IV) or protective group in which each rat was given curcumin as group (II) concomitant with aspartame as group (III) exactly.

The rats received single dose orally per day via gastric gavage for 8 weeks. At the end of the study, all animals were anesthetized byinjection of ketamine $(250 \mathrm{mg} / \mathrm{Kg} \text { intramuscular })^{[11]}$ then sacrificed by decapitation and the cerebellum was carefully removed and small pieces of it were fixed in buffered formalin (10\%).

\subsection{Histological study :}

Pieces of the cerebellum were processed and paraffin sections ( $5 \mu \mathrm{m}$ thick) were prepared then stained with the following stains:

-Hematoxylin and Eosin ${ }^{[12]}$.

-Immunohistochemistry was done for the cerebellar sections for demonstration of astrocytes by GFAP (Glial Fibrillary Acidic Protein) and demonstation of apoptosis by caspase- $3^{[13]}$. [GFAP, Ab-1 (Clone GA -5) is a mouse monoclonal IgG, cat \# MS-280-R7, Thermo Fisher Scientific, Lab Vision Corporation] and Caspase-3 (CPP32 ) Ab-4, rabbit polyclonal IgG, cat \# RB-1197-R7,
Thermo Fisher Scientific, Lab Vision Corporation], caspase-3 reaction is mainly cytoplasmic with some nuclear staining. Avidin biotin peroxidase technique used for detection of the antibody. Light microscopic examination was done for cerebellar stained sections by OLYMPUS C5060-ADU 5HO1155 photomicroscope (Japan) in Histology and Cell Biology department, Faculty of Medicine, Zagazig University. Positive cells for GFAP and caspase 3 immunoreaction appeared brown .

\subsection{Morphometric study :}

The morphometric study was performed using Image J software (Wayne Rasband, National Institute of Mental Health, Bethesda, Maryland, USA). The number of normal purkinje cells were measured in $\mathrm{H}$ \& E stained sections, area percentage of GFAP immunoexpression from the total area of cerebellar cortex was measured in GFAP immune stained cerebellar sections and the optical density of caspase 3 immunoexpression of purkinje cells was measured. All measurements were performed at magnification X400 in 6 non overlapping fields in 6 random sections in 6 different rats in each group.

\subsection{Statistical study :}

SPSS 22 statistical software (IBM Corp. Armonk, NY, USA) was used for statistical study. Arithmetic means \pm standard deviation ( SD ) of the data were presented. One-way analysis of variance (ANOVA) followed by Post Hoc test were used to calculate the probability $(P)$ value. The statistical results were significant when $(P)$ value less than or equal 0.05 .

\section{RESULTS}

On general examination of the rats, 6 rats of the aspartame group exhibited loss of equilibrium with reduction of the activity while the protective group showed only reduction of the activity of the rats in 4 rats. No neurological signs were observed in other groups. Also, no death was recorded of the rats during this work.

\subsection{Light microscopic results :}

In the control groups (IA, IB ) and curcumin group (II), the histological and immunohistochemical examination of cerebellar sections showed nearly similar findings and no observable differences were noted. The H \& E stained sections of the control group showed normal histological appearance of the three layers of the cerebellar cortex that are outer molecular, middle purkinje cell and inner granular layers. The molecular layer contained few small cells (stellate cells present superficially with basket cells present more deep near the purkinje cell layer). The middle purkinje layer formed of pyriform cells arranged in one row and showed large vesicular rounded nuclei with prominent nucleoli and basophilic cytoplasm. The inner granular layer formed of tightly packed numerous deep 
stained cells and among these cells there were acidophilic non cellular spaces representing cerebellar islands (Fig. 1).

The sections stained with immunohistochemical GFAP showed few small postive astrocytes cells in between the granular cells with faint thin processes in the molecular layer (Fig. 2) while the sections stained with immunohistochemical caspase-3 apoptotic marker showed negative immuno reaction in different layers of the cerebellar cortex, also very faint brown cytoplasmic immuno reaction of purkinje cells was observed (Fig. 3).

Group III (aspartame group): Examination of H\&E stained sections of the cerebellar cortex of this group showed variable forms of affection in which some purkinje cells appeared shrunken, and some were deformed and appeared as cytoplasmic remnants loosing their pyriform shape as well as apparent empty spaces denoting absence of purkinje cells. There was focal hemorrhage in the molecular layer and perineural spaces around nerve cells. Also, spaces of neuropil loss among the granular cells were observed (Fig. 4). Also, areas of neuropil loss appeared around affected purkinje cells that had deep stained cytoplasm and dark stained nuclei (Fig. 5). In some areas of cerebellar cortex, irregular arrangement of purkinje cells with wide areas of neuropil loss (Fig. 6).

The sections stained with immunohistochemical GFAP showed increase in the size and number of brownish positive immunoreacted astrocytes in the granular layer and purkinje layer. Also, the molecular layer showed high positive brownish immunoreaction in the cell processes (Fig. 7).

Immunohistochemical stained sections for caspase-3 apoptotic marker showed increase of the number of thepurkinje cells that showed strong positive brownish cytoplasmic reaction that referred to cell apoptosis (Fig. 8)

Group IV (protective group) : Partial protection of the cerebellar cortex from the effect of aspartame intake was recorded as in the following: Examination of H\&E stained sections of cerebellar cortex of this group showed normal arrangement of purkinje cells in one layer and a number of these cells appeared normal (pyriform shape with central vesicular nuclei) while some purkinje cells were affected. Few vacuolated areas appeared in the granular layer (Fig. 9).

In sections stained with immunohistochemical GFAP, the astrocytes in the granular layer decreased in number and the intensity of brownish immunoreaction of their cells was decreased, also in the molecular layer the processes of astrocytes showed less brownish immunoreactive when compared to that of the aspartame group (Fig.10).

In sections stained with immunohistochemical caspase-3, few purkinje cells showed strong brown positive immunoreaction while most of purkinje cells showed mild ornegative reaction when compared to that of the aspartame group ( Fig.11) .

\subsection{Morphometric results :}

In all morphometric parameters (Number of normal purkinje cells, area percentage of GFAP immunoexpression and the optical density of caspase-3 immunoexpression of purkinje cells) no statistical difference was found between the results of the control groups (IA, IB), so the group- IA (control group) was used to be compared with other groups. Morphometric analysis of the results of aspartame treated group when compared with the control group revealed significant decrease of number of normal purkinje cells $(P<0.001)$, also significant increase of area percentage of GFAP immunoexpression and the optical density of caspase 3 immunoexpressionof purkinje cells was increased $(P<0.001)$. The changes of the previous parameters were reduced partially in the protective group when compared with the aspartame $\operatorname{group}(P<0.001)$, but did not reach their levels in the control group as shown in Tables 1, 2 .

Table 1: Morphometric analysis of number of normal purkinje cells , area percentage of GFAP immunoexpression and the optical density of caspase 3 immunoexpression of purkinje cells in different groups .

\begin{tabular}{|c|c|c|c|c|c|}
\hline & $\begin{array}{c}\text { Group I } \\
\text { Mean } \pm \text { SD }\end{array}$ & $\begin{array}{c}\text { Group II } \\
\text { Mean } \pm \text { SD }\end{array}$ & $\begin{array}{c}\text { Group III } \\
\text { Mean } \pm \text { SD }\end{array}$ & $\begin{array}{c}\text { Group IV } \\
\text { Mean } \pm \text { SD }\end{array}$ & $P$ value \\
\hline Number of normal purkinje cells & $6.16 \pm 0.75$ & $6 \pm 0.63$ & $1.16 \pm 0.40$ & $4.00 \pm 0.63$ & $0.000^{* * *}$ \\
\hline Area percentage of GFAP immunoexpression & $4.33 \pm 0.23$ & $4.32 \pm 0.19$ & $11.06 \pm 0.86$ & $5.85 \pm 0.53$ & $0.000^{* * *}$ \\
\hline $\begin{array}{l}\text { Optical density of caspase } 3 \text { immunoexpression of purkinje } \\
\text { cells }\end{array}$ & $0.180 \pm 0.020$ & $0.176 \pm 0.010$ & $0.685 \pm 0.068$ & $0.303 \pm 0.162$ & $0.000^{* * *}$ \\
\hline
\end{tabular}

SD: standard deviation $\quad * * *$ : significant $(P<0.001)$ 
Table 2: Showing comparison of number of normal purkinje cells, area percentage of GFAP immunoexpression and the optical density of caspase-3 immunoexpression of purkinje cells in different groups by using Post Hoc test (LSD)

\begin{tabular}{|c|c|c|c|c|c|c|}
\hline & $\begin{array}{l}\text { Group I versus } \\
\text { Group II }\end{array}$ & $\begin{array}{l}\text { Group I } \\
\text { versus } \\
\text { Group III }\end{array}$ & $\begin{array}{l}\text { Group I versus } \\
\text { Group IV }\end{array}$ & $\begin{array}{l}\text { Group II } \\
\text { versus } \\
\text { Group III }\end{array}$ & $\begin{array}{l}\text { Group II } \\
\text { versus } \\
\text { Group IV }\end{array}$ & $\begin{array}{l}\text { Group III } \\
\text { versus } \\
\text { Group IV }\end{array}$ \\
\hline Number of normal purkinje cells & $\begin{array}{c}(P \text { value }) \\
0.646^{\mathrm{NS}}\end{array}$ & $\begin{array}{l}(P \text { value }) \\
0.000^{* * *}\end{array}$ & $\begin{array}{l}(P \text { value }) \\
0.000^{* * *}\end{array}$ & $\begin{array}{l}(P \text { value }) \\
0.000^{* * *}\end{array}$ & $\begin{array}{l}(P \text { value }) \\
0.000^{* * *}\end{array}$ & $\begin{array}{l}(P \text { value }) \\
0.000^{* * *}\end{array}$ \\
\hline $\begin{array}{l}\text { Area percentage of GFAP } \\
\text { immunoexpression }\end{array}$ & $\begin{array}{l}(P \text { value }) \\
0.951^{\mathrm{NS}}\end{array}$ & $\begin{array}{l}(P \text { value }) \\
0.000^{* * *}\end{array}$ & $\begin{array}{l}(P \text { value }) \\
0.000^{* * *}\end{array}$ & $\begin{array}{l}(P \text { value }) \\
0.000^{* * *}\end{array}$ & $\begin{array}{l}(P \text { value }) \\
0.000^{* * *}\end{array}$ & $\begin{array}{l}(P \text { value }) \\
0.000^{* * *}\end{array}$ \\
\hline $\begin{array}{l}\text { Optical density of caspase } 3 \\
\text { immunoexpression of purkinje } \\
\text { cells }\end{array}$ & $\begin{array}{c}(P \text { value }) \\
0.949^{\mathrm{NS}}\end{array}$ & $\begin{array}{l}(P \text { value }) \\
0.000^{* * *}\end{array}$ & $\begin{array}{l}(P \text { value }) \\
0.026^{*}\end{array}$ & $\begin{array}{l}(P \text { value }) \\
0.000^{* * *}\end{array}$ & $\begin{array}{l}(P \text { value }) \\
0.022^{*}\end{array}$ & $\begin{array}{l}(P \text { value }) \\
0.000^{* * *}\end{array}$ \\
\hline
\end{tabular}

NS: non significant, *: significant $0.05>P$ value $>0.01, * * *$ : significant $(P<0.001)$

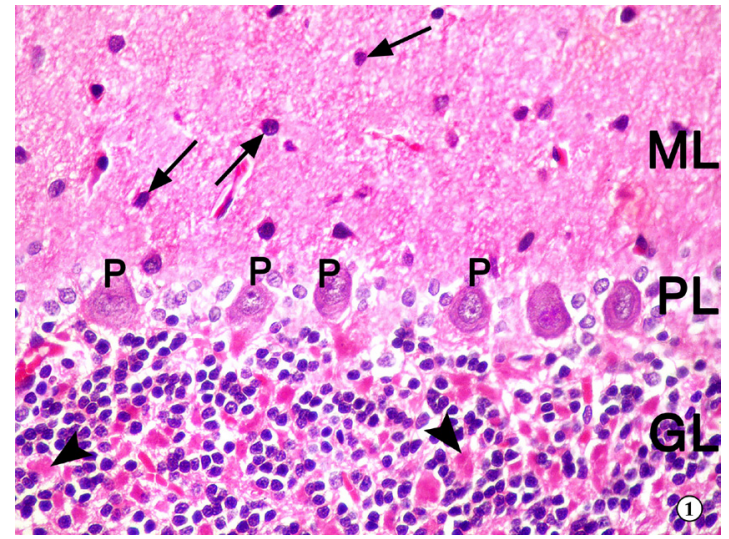

Fig. 1: A Photomicrograph of a section of the adult rat cerebellar cortex of a control group. [ Outer molecular layer (ML) contains few nerve cells (arrows) and Middle purkinje layer (PL) showing large pyriform cells $(\mathrm{P})$ with vesicular nuclei and apparent nucleoli\& Inner granular layer (GL) that having small rounded tightly packed cells ], also between the granular cells, there are acidophilic areas ( cerebellar islands) (arrow heads) (H\&E x400)

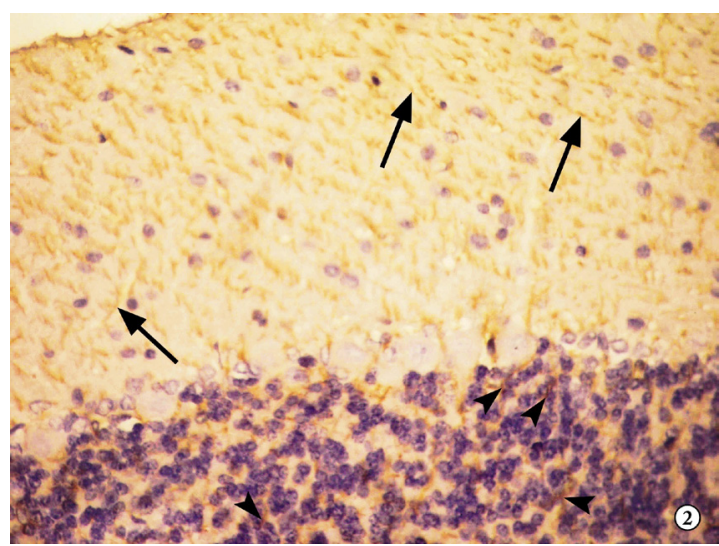

Fig. 2: A photomicrograph of immunohistochemical staining for GFAP in theadult rat cerebellar cortex of control group . GFAP positive brown astrocytes (arrow heads ) appear small with thin faint processes in the granular layer and also a faint immunoreaction in the cell processes (arrows) in the molecular layer (GFAP x400).

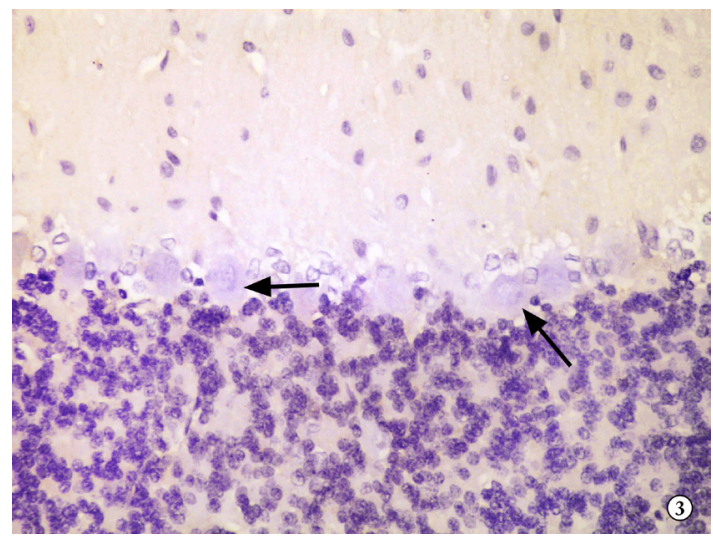

Fig. 3: A photomicrograph of a section of the adult rat cerebellar cortex of the control group. There is negative reaction for caspase- 3 in the different layers of cerebellar cortex and pyrkinje cells showing negative reaction (arrows) (caspase-3 $\times 400$ ).

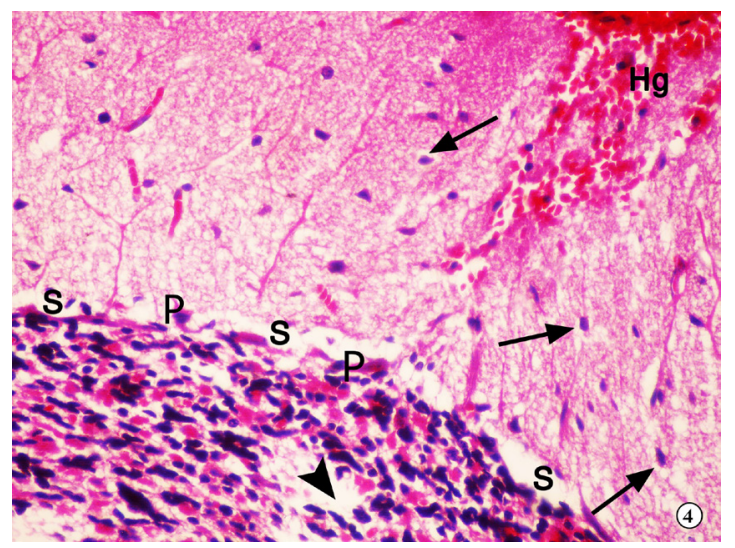

Fig. 4: A photomicrograph of a section of the adult rat cerebellar cortex of aspartame group. Loss and shrinkage of many purkinje cells $(\mathrm{P})$ in the purkinje layer leaving empty spaces $(\mathrm{S})$. Notice hemorrhage $(\mathrm{Hg})$ in the molecular layer, also perineural spaces (arrows) around its nerve cells. Areas of neuropil loss (arrow head )appear between cells of the granular layer (H\&E x400). 


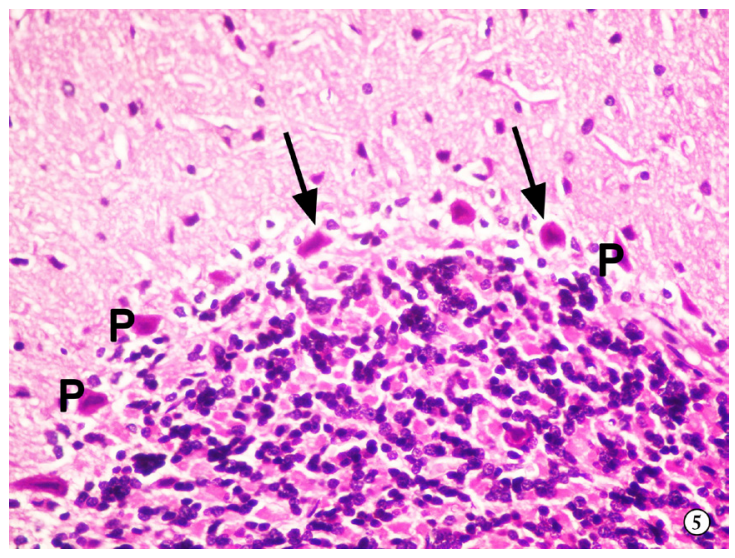

Fig. 5: A photomicrograph of a section of the adult rat cerebellar cortex of aspartame group .Purkinje cells have deep stained cytoplasm and small dark nuclei $(\mathrm{P})$. Areas of perineural spaces (arrows) appear around the affected purkinje cells (H\&E x 400).

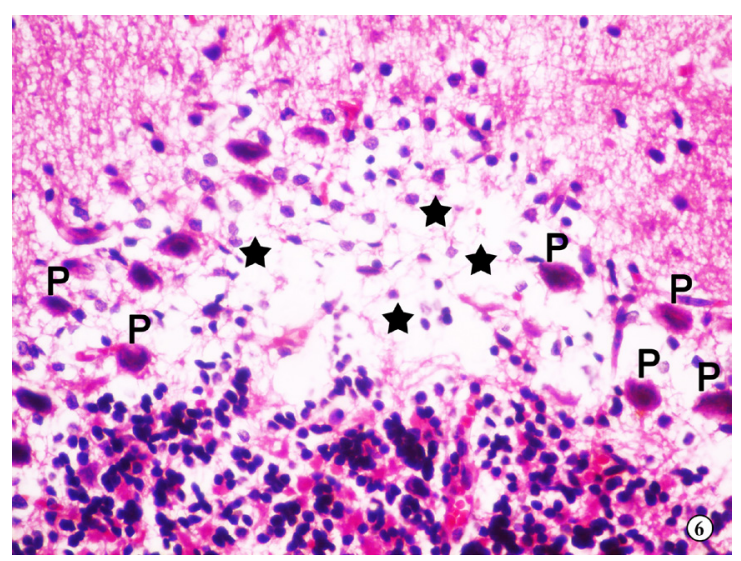

Fig. 6: A photomicrograph of a section of the adult rat cerebellar cortex of aspartame group. Irregular arrangement of purkinje cells ( P) with wide areas of neuropil loss (stars) (H\&E x400).

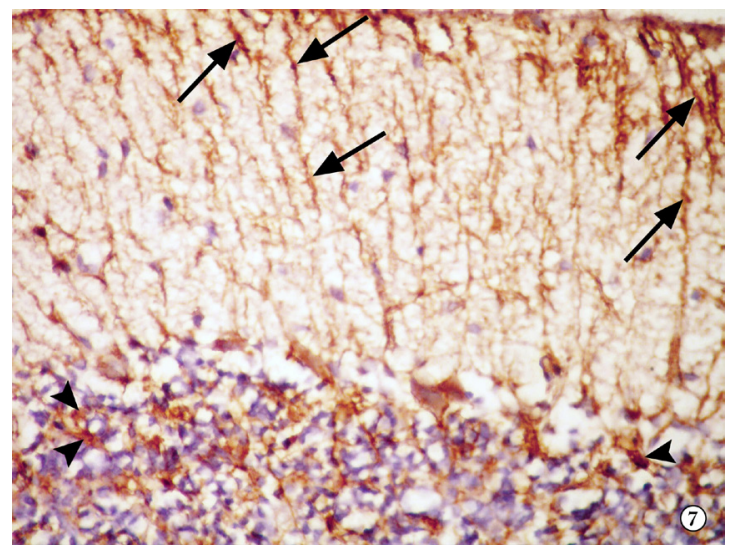

Fig. 7: A photomicrograph of a section of the adult rat cerebellar cortex of aspartame group. The immunoreaction for GFAP in the three layers of cerebellar cortex is increased, GFAP positive astrocytes (arrow heads) with thick processes in the granular layer. Also, deeply brownish immunoreaction in the cell processes (arrows) in the molecular layer (GFAP x400).

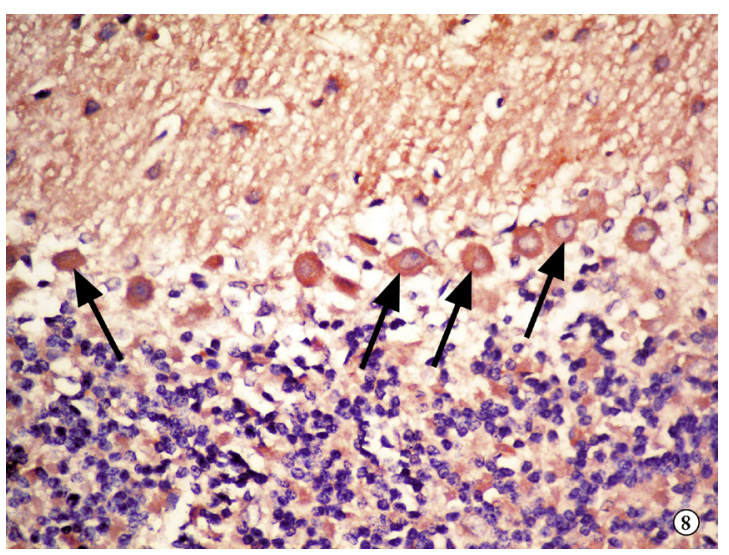

Fig. 8: A photomicrograph of a section of the adult rat cerebellar cortex of aspartame group. There is strong positive brown immunoreaction for caspase- 3 in the cytoplasm of purkinje cells (arrows) (caspase-3 x400).

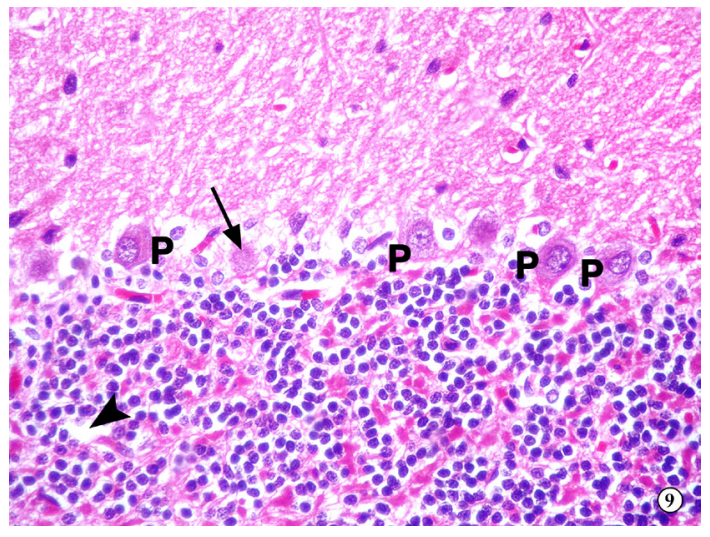

Fig. 9: A photomicrograph of a section of the adult rat cerebellar cortex of the protective group. Some purkinje cells (p) appear normal with vesicular nuclei and other purkinje cells are affected (arrow), few vacuolated areas (arrow head) appear in the granular layer $(H \& E$ x 400)

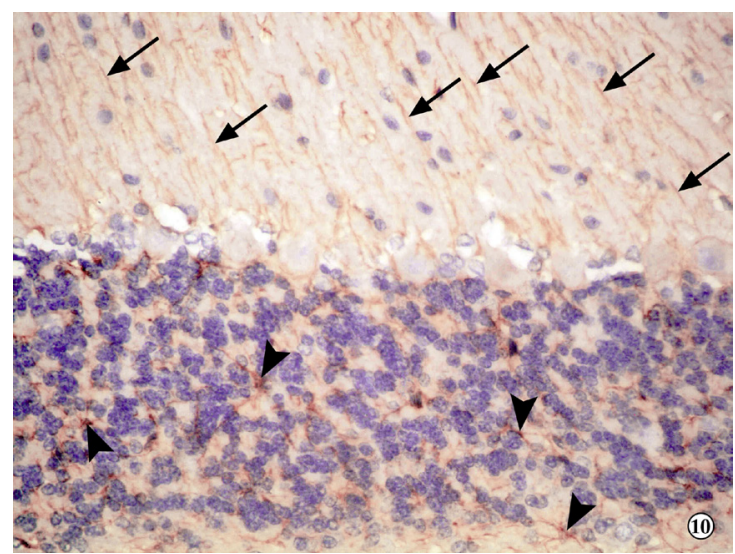

Fig. 10: A photomicrograph of a section of the adult rat cerebellar cortex of the protective group. Moderate size and intensity of immunoreactive GFAP positive astrocytes (arrow heads) appear in the granular layer and moderate immunoreactive cell processes in the molecular layer (arrows) (GFAP x400). 


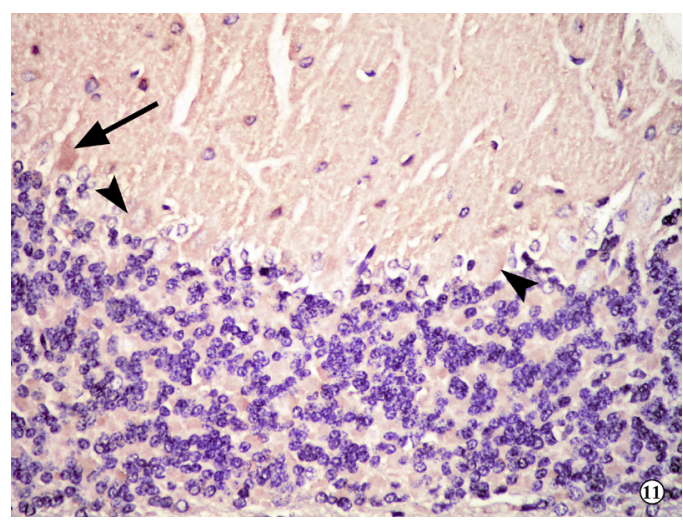

Fig. 11: A photomicrograph of a section of the adult rat cerebellar cortex of the protective group. Mild brownish immunoreaction for caspase 3 appears in most of purkinje cells (arrow heads) while strong positive reaction for caspase3 (arrow) appear in few purkinje cells (caspase-3 x400).

\section{DISCUSSION}

Aspartame is an artificial and most popular sweetener that is used by many persons for diet control ${ }^{[14,15]}$. Aspartame and its components may be a cause of different neurological symptoms ${ }^{[6]}$. Purkinje cells of the cerebellum that are involved in the process of learning and motor action are susceptible to environmental factors that may disrupt their functions ${ }^{[16]}$.

In this study, the H\&E stained cerebellar sections in the aspartame treated group showed absence or shrunked purkinje cells, also there were areas of neuropil loss around the purkinje cells and in the granular layer. These findings agreed with other studies that referred the pericellular spaces appeared around purkinje cells and granular cells due to shrinkage of their cells ${ }^{[17]}$. Deep stained purkinje cells with dark stained nuclei also appeared in aspartame group and some studies revealed that aspartame consumption was associated with neuronal degeneration and pyknotic nuclei ${ }^{[18]}$. Majno and Joris ${ }^{[19]}$ revealed that the dark stained purkinje cells refers to denatured proteins and its accumulation as a result of failure of antioxidant defense system.

Aspartame is metabolized in the intestine into triple components that are phenylalanine, aspartate that also called aspartic acid and methanol ${ }^{[20]}$. Phenylalanine that forms $50 \%$ of the components of aspartame can cross the blood brain barrier and decreases the level of catecholamines $^{[4]}$. Aspartate that is another component of aspartame (forms $40 \%$ of aspartame) is excitatory neurotransmitter in the cerebellum ${ }^{[21]}$ and is similar to glutamate in its structure, also aspartate and glutamate are normally found neurotransmitters in the central nervous system and become neurotoxic when their levels increased more than the critical values ${ }^{[6]}$. Some studies revealed that aspartate might cause excitation of the brain cells till death $^{[13]}$. Methanol is the 3rd component of aspartame ( forms $10 \%$ of aspartame ) and converted to formaldehyde in the liver ${ }^{[4]}$. Formaldehyde is considered as a neurotoxin that is attached to proteins and DNA of different cells and might lead to breaking of DNA ${ }^{[13]}$. These findings explain changes occurring in purkinje cells in this work. Also, methanol leads to oxidative stress and increases the level of lipid peroxidation and the free radicals ${ }^{[22]}$.

Abdel-Salam et al. ${ }^{[23]}$ reported that aspartame increases the oxidative stress in the mice brain and Abhilash et al. ${ }^{[24]}$ added that it affects the antioxidant defense mechanism in the brain.

In this study, the hemorrhage appeared in the molecular layer of H\&E stained cerebellar sections of the aspartame treated group might be as a result of metabolism of aspartame and production of formaldehyde that is cytotoxic to the endothelial lining of the blood vessels, resulting in lack of the clotting factors and bleeding ${ }^{[25]}$.

GFAP is a specific marker for demonstration of astrocytes ${ }^{[26]}$ that play a role in repairing the damage of the brain due to neurotoxicity ${ }^{[2]}$. Also, Mohamed ${ }^{[28]}$ stated that the neuronal injury by aspartame could result in proliferation of astrocytes.

In the present work, there was increasing of positive immunoreaction of GFAP in aspartame group and this might be due to neurodegeneration caused by aspartame intake. This was in agreement with other researches who revealed that there is increasing of gliofilaments after neuronal damage as a compensatory neuroprotective mechanism $^{[29]}$.

Also, there was increasing of positive immunoreaction of caspase-3 of purkinje cells in the aspartame group when compared with the control group and it was a sign of apoptosis. This finding is in agreement with other researches that reported that aspartic acid increases calcium movement by activation of the calcium channels on the cell membrane ${ }^{[6]}$, the excess calcium is sequestrated in the mitochondria leading to its affection and releases of cytochrome $\mathrm{c}$ that is the key enzyme involved in the oxidative phosphorylation and activation of caspase- 9 and caspase-3 which to initiate apoptosis ${ }^{[30]}$.

Curcumin is used in various types of foods as potato chips, mustard and also in cosmetics ${ }^{[31]}$. Curcumin induces potent antioxidant effect ${ }^{[8]}$. Shukla et al. ${ }^{[32]}$ revealed that due to the antioxidant property of curcumin, it was suggested as an important treatment in many diseases. The authors added that oral administration of curcumin decreases the lipid peroxidation in the kidney, lung and liver treated rats with cyclophosphamide, also it protects against neurotoxicity in lead treated rats. Curcumin has a number of known actions including anti-oxidant and anti-inflammatory activities for treatment or protection of neurodegenerative 
diseases as cerebral stroke and Alzheimer's diseases ${ }^{[33]}$. Oxidative stress leads to mitochondrial dysfunction and mediates apoptosis ${ }^{[34]}$. Maintainance of mitochondrial function plays an important role in production of energy, calcium regulation and homeostasis of neurons ${ }^{[35]}$. Molina-Jijón et al. ${ }^{[36]}$ reported that curcumin protects against oxidant damage of the kidney as it preserves the function of mitochondria.

Curcumin activates the antioxidant enzymes ${ }^{[8]}$. The neuroprotective effect of curcumin may be due to its antioxidant mechanism and its activity in scavenging the free radicals ${ }^{[37,38]}$.

In this study, when curcumin concomitantly administrated with aspartame, it reduced the hazards of aspartame on the cerebellar cortex but the histological appearance of the cerebellar cortex was not completely normal and these results were parallel with highly significant decrease of GFAP area percentage, optical density of caspase-3 immunoreaction and with highly significant increase of number of normal purkinje cells when compared with the aspartame group, also the previous parameters in the protective group did not reach their values in the control group .

\section{CONCLUSION}

In conclusion curcumin intake partially can reduce the hazards of aspartame on the cerebellar cortex due to its antioxidant effect. So, supplementation of curcumin concomitantly with aspartame is recommended. Further studies may be needed for adjustment of the dose of curcumin to cope with the effect of aspartame on the cerebellar cortex or to begin pretreatment with curcumin earlier than aspartame intake .

\section{ACKNOWLEDGEMENT}

The author is grateful to members of the Animal House Unit, Faculty of Medicine, Zagazig University for allowing the experimental work in their laboratories.

\section{CONFLICTS OF INTEREST}

There are no conflicts of interest.

\section{REFERENCES}

1. Meyer H :Aspartame as part of the Solution.Food Sci.Technol.2005;19(4):43-45.

2. Beck B, Burlet A, Max JP and Stricker - krongrad
A: Effects of long-term ingestion of aspartame on hypothalamic neuropeptide Y, plasma leptin and body weight gain and composition . physiolBehav 2002;75(1-2):41 - 47 .

3. Soffritti M, Belpoggi F, Degli Esposti D, Lambertini L, Tibaldi E and Rigano A: First experimental demonstration of the multipotential carcinogenic effects of aspartame administered in the feed to Sprague - Dawley rats. Environ Health perspect ,2006; 114(3):379 - 385 .

4. Humphries P, Pretorius E and Naudé H: Direct and indirect cellular effects of aspartame on the brain. Eur J clinNutr 2008 ;62(4):451- 462.

5. Simintzi I, Schulpis KH, Angelogianni P, Liapi $\mathrm{C}$ and Tsakiris $\mathrm{S}$ : The effect of aspartame on acetylcholinesterase activity in hippocampal homogenates of suckling rats. Pharmacol. Res.2007; 56 (2)155-159.

6. Okasha EF: Effect of long term-administration of aspartame on the ultrastructure of sciatic nerve .Journal of Microscopy and Ultrastructure, $2016 ; 4: 175-183$.

7. Magnuson BA, Burdock GA, Doull J, Kroes RM, Marsh GM, Pariza MW and Williams GM: Aspartame :a safety evaluation based on current use levels, regulations and toxicological and epidemiological studies. Crit.Rev. Toxicol.2007;37(8):629- 727 .

8. González - Reyes S , Guzmán - Beltrán S, Medina - Campos ON and Pedraza - Chaverri $\mathrm{J}$ :curcumin Pretreatment Induces $\mathrm{Nrf2}$ and an Antioxidant Response and Prevent HeminInduced Toxicity in Primary Cultures of Cerebellar Granule Neurons of Rats. Oxid Med Cell Longev ,2013 ; Article ID 801418, doi.org/10.1155/2013/801418 .

9. Sayed MM and El-Kordy EA : The protective effect of curcumin on paracetamol-induced liver damage in adult male rabbits: biochemical and histological studies . Egyptian Journal of Histology, 2014 ; 37(4), 629-639.

10. Bayomy NA, Elshafey S H, Mosaed MM and Hegazy AM : Protective effect of curcumin versus $\mathrm{N}$-acetylcystein on acetaminophen induced hepatotoxicity in adult albino rats. Journal of Cytology and Histology, 2015 ; S3:018. doi:10.4172/2157-7099.S3-018 .

11. Uzunoglu S, Karagol H, Ozpuyan F, Cosar R, 
Cicin I and Yurutcaloglu V : Protective effect of L-carnitine versus amifostine against cisplatininduced nephrotoxicity in rats. Medical Oncology, 2011; 28(1) : S690-S696.

12. Bancroft $\mathrm{J}$ and Gamble $\mathrm{M}$ : Theory and practice of Histological technique (6th ed. ), Churchill Livingstone, London, 2008 ; PP: 165-175.

13. Abd El-Samad AA: Light and Electron Microscopic Study on the Effect of Aspartame on the Cerebellar Cortex of Male Albino Rat .Egypt. J. Histol. 2010; 33 (3):419-430 .

14. Duerfahrt T, Doekel S, Sonke T, Quaedflieg PJ and Marahiel MA: Construction of hybrid peptide Synthetases for the production of alpha -1- aspartyl -1- phenylalanine, a precursor for the high-intensity sweetener aspartame. Eur.J.Bio chem.2003;270(22):4555-4563.

15. Bressan CA, Finamor IA, da Silva Pês T, Bertolin $\mathrm{K}$, Garrido SP and Gonçalves PBD : N-acetylcysteine protects against changes in the glutathione related-system in mice brain caused by the administration of aspartame. Free Radical Biology and Medicine,2018; 120(1) : S48.

16. Minai M: "Purkinje Cells" . Embryo Project Encyclopedia, 2014; ISSN: 1940-5030 http://embryo.asu.edu/handle/10776/8144 .

17. Sobaniec W, kulak W, Bockowski L, SmigielskaKuzia J,Sobaniec-Lotowska M, Solowiej Eand Artemowicz B: Studies of damaged processes in the nervous system and possibilities of neuroprotection. Przegllek. 2001; 58 (suppl 1) :41 - 47 .

18. Mohamed AS , El-Shinnawy NA and Abd Elmageid SA : Difference between natural and artificial sweeteners: Histopathological studies on male albino rat's brain (hippocampus). Journal of Scientific Research in Science, 2019; 36(1), 120-139.

19. Majno $G$ and Joris I :Apoptosis,oncosis, and necrosis : Anoverview of cell death. Am J Pathol. $1995 ; 146(1): 3-15$.

20. Hassen EZ, Mahmoud AA, Ibrahem NE and ElShal AS : The Effect of Long Term Administration of Aspartame on the Sciatic nerve of adult male albino rats and the Possible Therapeutic Role of Ozone (Histological and Biochemical
Study). Egyptian Journal of Histology, 2019; 42(1), 191-201.

21. Christian B, McConnaughey K, Bethea E, Brantley S, Coffey A, Hammond L and Brinson $\mathrm{L}:$ Chronic aspartame affects T-maze performance, brain cholinergic receptors and $\mathrm{Na}+, \mathrm{K}+-$ ATPase in rats. PharmacolBiochemBehav.2004; 78(1): $121-127$

22. Ashok I ,Sheeladevi R and Wankhar D :Acute effect of aspartame -induced oxidative stress in Wistar albino rat brain. J Biomed Res. 2015 ; 29(5): $390-396$.

23. Abdel- Salam OM, Salem NA, EL- Shamarka ME, Hussein JS, Ahmed NA and EL-Nagar $\mathrm{ME}$ : Studies on the effects of aspartame on memory and oxidative stress in brain of mice. Eur Rev Med Pharmacol Sci. 2012 ;16(15):2092-2101.

24. Abhilash M ,Sauganth Paul MV, Varghese MV and Nair RH : Long- term consumption of aspartame and brain antioxidant defense status. Drug ChemToxicol. 2013 ; 36(2): 135-140.

25. Maaruf NAAQ, Mahmood ZM and Abdulhameed TT : Effect of Aspartame on the Liver of Male Albino Rats: A Histopathological and Immunohistochemical Study. Medical Journal of Babylon, 2017; 14(3), 558-566.

26. Der Perng M, Su M , Wen SF, Li R., Gibbon T, Prescott AR, Brenner M and Quinlan RA : The Alexander Disease - Causing Glial Fibrillary Acidic Protein Mutant, R416W, Accumulates into Rosenthal Fibers by a Pathway That Involves Filament Aggregation and the Association of $\alpha$ B - Crystallin and HSP27. AM. J. Hum. Genet. 2006; 79(2) : $197-213$.

27. Li DR, Ishikawa T, Zhao D, Michiue T, QuanL, Zhu BL and Maeda $\mathrm{H}$ : Histopathologicalchanges of the hippocampus neurons in brain injury. Histol. Histopathol. 2009 ;24(9): 1113-1120.

28. Mohamed NA: Chronic effect of aspartame versus stevioside on the cerebellar cortex of the adult albino rat: a histological and immunohistochemical study. Egyptian Journal of Histology, 2013;36(1), 213-232.

29. Al-Hayani A, Elshal EB, Abdel Aal IH and AlShammeri E : Does vitamin E protect against sodium fluoride toxicity on the cerebellar cortex 
of albino rats. Middle-East Journal of Scientific Research, 2013; 16(7), 1019-1026.

30. Zhang YM and Bhavnani BR : Glutamate induced apoptosis in neuronal cells is mediated via caspase - dependent and independent mechanisms involving calpain and caspase-3 proteases as well as apoptosis inducing factor (AIF) and this process is inhibited by equine estrogens. BMC Neurosci.2006 ; 7(49) doi:10.1186/1471-2202-7-49.

31. Cekmen M, Ilbey YO,Ozbek E,Simsek A, Somay $\mathrm{A}$ and Ersoz $\mathrm{C}$ :Curcumin prevents oxidative renal damage induced by acetaminophen in rats. Food ChemToxicol. 2009 ; 47:1480 - 1484.

32. Shukla PK, Khanna VK, Khan MY and Srimal RC : Protective effect of curcumin against lead neurotoxicity in rat. Hum Exp Toxicol. $2003 ; 22: 653-658$.

33. Cole GM, Teter B and Frautschy SA : Neuroprotective effects of curcumin. Adv. Exp. Med. Biol. 2007 ; 595 :197-212.

34. Serbecic N and Beutelspacher SC : Anti - oxidative vitamins prevent lipid- peroxidation and apoptosis in corneal endothelial cells. Cell and Tissue Research,2005; 320(3): 465 - 475.

35. Tilson HA, Hong JS and Sobotka TJ: High doses of aspartame have no effects on sensorimotor function or learning and memory in rats. NeurotoxicolTeratol.1991;13(1):27-35.

36. Molina- Jijón E, Tapia E, Zazueta C, EL Hafidi M, Zatarain - Barrón ZL, Hernández-Pando $\mathrm{R}$, Medina-Campos $\mathrm{ON}$ and Pedraza-Chaverri, $\mathrm{J}$ :Curcumin prevents $\mathrm{Cr}$ (VI)-induced renal oxidant damage by a mitochondrial pathway. Free RadicBiol Med.2011 ; 51(8) : 1543 - 1557.

37. $A K T$ and Gülcin I: Antioxidant and radical scavengingproperties of curcumin. ChemBiol Interact. 2008;174 (1) :27- 37.

38. Borra SK, Gurumurthy P, Mahendra J, Jayamathi $\mathrm{KM}$,Cherian $\mathrm{CN}$ and Chand $\mathrm{R}$ : Antioxidant and free radical scavenging activity of curcumin determined by using different in vitro and ex vivo models. J. Med Plants Res.2013 ; 7(36):2680-2690 
الملخص العربى

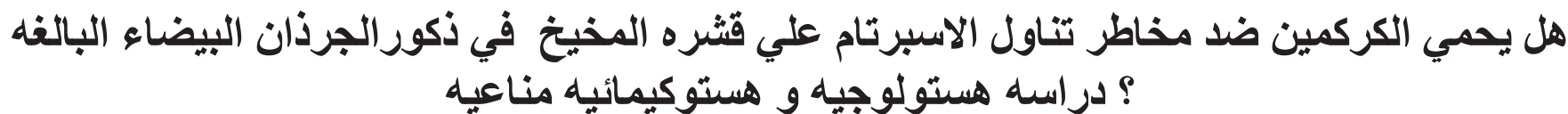

$$
\text { ابراهيم حسن ابراهيم }
$$

قسم التشريح و الأجنه ، كلية الطب البشري ، جامعة الزقازيق ، محافظة الشرقية ، جمهورية مصر

الخلفية: ان الاسبرتام محلي صناعي يستخدم في العديد من الأطعمة والمشروبات ولكن لأنس للأسف الاسبرتام لله مخاطر علي قثره

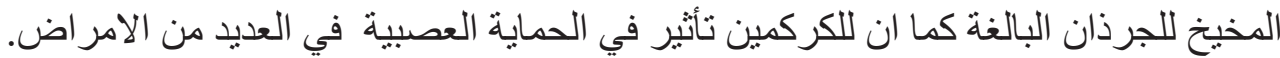

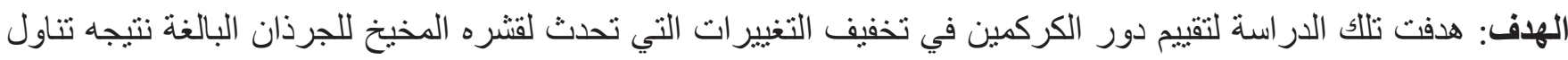

$$
\text { الاسبرتام. }
$$

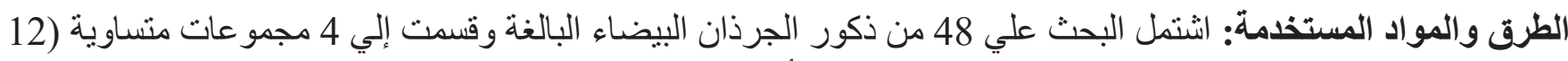

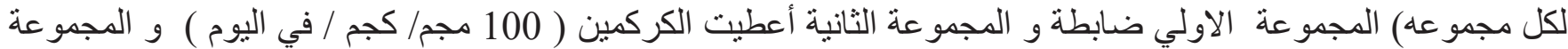

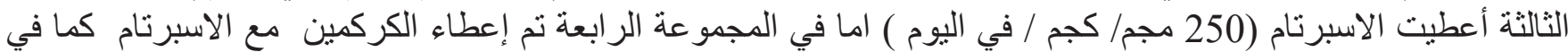

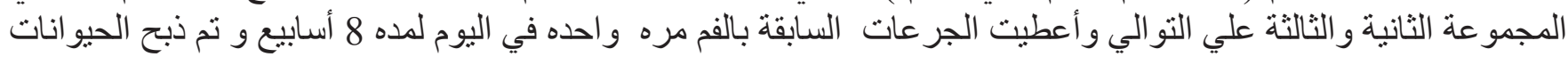

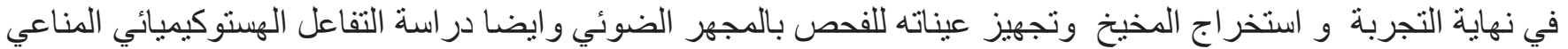
لكل من البروتين اللليفي الحمضي للخليه الدبقيه و للكسبيز 3- و وعل در اسات قياسيه و إحصائية للنتائج.

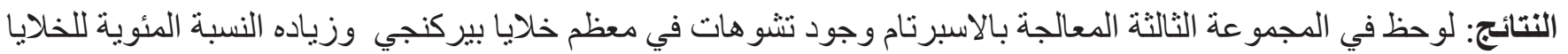

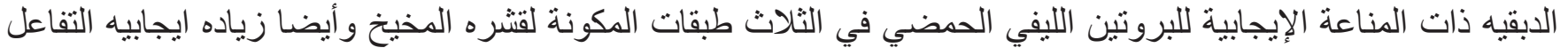

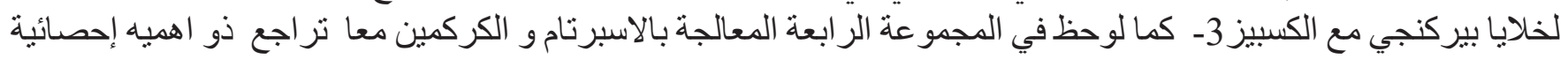

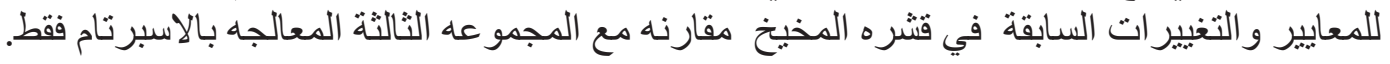

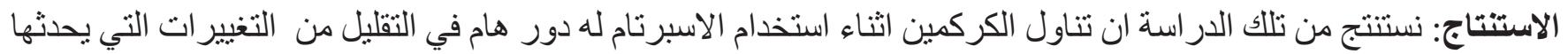

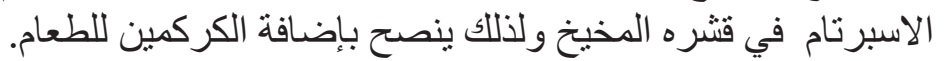

